\title{
Ocular Adnexal Lymphoma pT4b TNM
} Finding v7

National Cancer Institute

\section{Source}

National Cancer Institute. Ocular Adnexal Lymphoma pT 4b TNM Finding v7. NCI

Thesaurus. Code C88844.

Osseous involvement (including periosteum). (from AJCC 7th Ed.) 